Principles of Animal Locomotion 



\section{Principles of Animal Locomotion}

R. McNeill Alexander

PRINCETON UNIVERSITY PRESS

PRINCETON AND OXFORD 
Copyright $\odot 2003$ by Princeton University Press

Published by Princeton University Press, 41 William Street,

Princeton, New Jersey 08540

In the United Kingdom: Princeton University Press,

3 Market Place, Woodstock, Oxfordshire OX20 1SY

All Rights Reserved

Second printing, and first paperback printing, 2006

Paperback ISBN-13: 978-0-691-12634-0

Paperback ISBN-10: 0-691-12634-8

The Library of Congress has cataloged the cloth edition of this book as follows

Alexander, R. McNeill.

Principles of animal locomotion / R. McNeill Alexander.

p. $\mathrm{cm}$.

Includes bibliographical references (p. ).

ISBN 0-691-08678-8 (alk. paper)

1. Animal locomotion. I. Title.

QP301.A2963 2002

$591.47^{\prime} 9-\mathrm{dc} 21 \quad 2002016904$

British Library Cataloging-in-Publication Data is available

This book has been composed in Galliard and Bulmer

Printed on acid-free paper. $\infty$

pup.princeton.edu

Printed in the United States of America

$\begin{array}{lllllllll}10 & 9 & 8 & 7 & 6 & 5 & 4 & 3 & 2\end{array}$ 